\title{
Correction to: High-Dimensional Quadratic Classifiers in Non-sparse Settings
}

\author{
Makoto Aoshima $^{1} \cdot K_{\text {Kazuyoshi Yata }}{ }^{1}$
}

Published online: 26 December 2021

(CThe Author(s) 2021

\section{Correction to: Methodol Comput Appl Probab (2019) 21(3):663-682 https://doi.org/10.1007/s11009-018-9646-z}

The article High-Dimensional Quadratic Classifiers in Non-sparse Settings, written by Makoto Aoshima and Kazuyoshi Yata, was originally published Online First without Open Access. After publication in volume 21, issue 3, page 663-682 the author decided to opt for Open Choice and to make the article an Open Access publication. Therefore, the copyright of the article has been changed to (OThe Author(s) 2021 and the article is forthwith distributed under the terms of the Creative Commons Attribution 4.0 International License, which permits use, sharing, adaptation, distribution and reproduction in any medium or format, as long as you give appropriate credit to the original author(s) and the source, provide a link to the Creative Commons license, and indicate if changes were made. The images or other third party material in this article are included in the article's Creative Commons license, unless indicated otherwise in a credit line to the material. If material is not included in the article's Creative Commons license and your intended use is not permitted by statutory regulation or exceeds the permitted use, you will need to obtain permission directly from the copyright holder. To view a copy of this licence, visit http://creativecommons.org/licenses/ by-nc/4.0.

The original article has been corrected.

Publisher's Note Springer Nature remains neutral with regard to jurisdictional claims in published maps and institutional affiliations.

The original article can be found online at https://doi.org/10.1007/s11009-018-9646-z.

Makoto Aoshima

aoshima@math.tsukuba.ac.jp

Kazuyoshi Yata

yata@math.tsukuba.ac.jp

1 Institute of Mathematics, University of Tsukuba, Ibaraki 305-8571, Japan 